Short Communication

\title{
Copper-Doped Iron Carbide as Counter Electrodes for Dye- Sensitized Solar Cells
}

\author{
Haopeng Cai ${ }^{1, *}$, Jie $\mathrm{Li}^{1,2}$, Rui Wang ${ }^{2}$, Fanglin Wu ${ }^{2}$, Xing Tong ${ }^{1,2}$ \\ ${ }^{1}$ School of Materials Science and Engineering, Wuhan University of Technology, Wuhan 430070, PR \\ China. \\ ${ }^{2}$ State Key Laboratory of Advanced Technology for Materials Synthesis and Processing, Wuhan \\ University of Technology, Wuhan 430070, P. R. China. \\ *E-mail: cai_haopeng@whut.edu.cn
}

doi: $10.20964 / 2017.09 .50$

Received: 14 June 2017 / Accepted: 12 July 2017 / Published: 13 August 2017

\begin{abstract}
A facile method of pyrolysis of 2-methyl imidazole is used to prepare copper-doped iron carbide materials as counter electrodes for dye-sensitized solar cells. The content of copper in copper doped iron carbide materials are: $0.25 \%, 0.5 \%, 0.75 \%, 1 \%$ (molecular proportion). Among these DSSCs made from different $\mathrm{Cu}$ content $\mathrm{Fe}_{3} \mathrm{C}$ cathodes, the $\mathrm{Fe}_{3} \mathrm{C}-0.75 \% \mathrm{Cu}$ based on the $\mathrm{Cu}$ content of $0.75 \%$ counter electrode yields the highest energy conversion efficiency of 5.68\%. Compared to the $\mathrm{Pt} / \mathrm{C}$ based DSSC $(6.22 \%)$, the DSSC fabricated from $\mathrm{Fe}_{3} \mathrm{C}-0.75 \% \mathrm{Cu}$ has a similar $\eta$. To evaluate the chemical catalysis of copper-doped iron carbide counter electrodes toward $I_{3}^{-}$reduction, cyclic voltammetry and electrochemical impedance spectra are carried out to characterize the counter electrodes. All the results have revealed that doped with copper can improve the catalytic ability of iron carbide counter electrodes. And the copper doped iron carbide counter electrode owns low prices of raw materials, simple production process, so it has very wide application prospects.
\end{abstract}

Keywords: copper-doped; iron carbide; counter electrodes; DSSC

\section{$\underline{\text { FULL TEXT }}$}

(C) 2017 The Authors. Published by ESG (www.electrochemsci.org). This article is an open access article distributed under the terms and conditions of the Creative Commons Attribution license (http://creativecommons.org/licenses/by/4.0/). 